\title{
Poaching vs. patrolling: effects on conservation of Cory's Shearwater Calonectris diomedea borealis colonies
}

\author{
MARTA LOPEZ-DARIAS, JAVIER LUZARDO, RAFAEL MARTÍNEZ, \\ DANIEL GONZÁLEZ, EDUARDO A. GARCÍA and JEREMÍAS CABRERA
}

\section{Summary}

Negative effects of poaching on seabird populations are not usually evaluated quantitatively when assessing seabird colony conservation status, nor are they generally considered a major concern. We demonstrate that poaching is still intense in the Canary Islands, and has negative consequences for the conservation of seabird colonies. We quantified the effects of poaching of Cory's Shearwater fledglings on breeding success on different islands in the Canaries, comparing colonies that suffer from intense, medium, or no poaching. Poaching reduced the breeding success of affected colonies to almost a third, potentially causing the future extinction of the colony. Only colonies with intense wardening campaigns reached high values of reproductive success, showing that government surveillance in conjunction with volunteers from different NGOs is a very effective approach in reducing poaching. A population sensitivity analysis was also conducted to provide data on the factors that most affect the performance of the model. Although population growth and mean final population size varied with increases and decreases in mortality and carrying capacity, only harvesting resulted in a probability of $100 \%$ of extinction in 20-40 years. To promote seabird conservation in regions such as the Canary Islands, a core archipelago for seabird species in the Atlantic, poaching control should be elevated by society to a level of urgency, requiring dedicated funding and mobilisation of experts and volunteers to adequately address it through education, prevention and enforcement.

\section{Resumen}

Los efectos negativos de la caza furtiva en las poblaciones de aves marinas no suelen ser considerados cuantitativamente a ; it should says: "cuantitativamente a la hora" la hora de evaluar el estado de conservación de las colonias de aves marinas, tampoco se les considera una de las principales preocupaciones. Nosotros demostramos que la caza furtiva sigue siendo intensa en las Islas Canarias y tiene consecuencias negativas para la conservación de las colonias. Cuantificamos los efectos de la caza furtiva sobre pollos volanderos de Pardela cenicienta en el éxito reproductivo de la especie en distintas islas de las Canarias, comparando colonias que sufren desde intensa, a media, o a ninguna caza furtiva. La caza furtiva redujo el éxito reproductor de las colonias afectadas a casi un tercio, lo que podría causar la extinción futura de la colonia. Sólo las colonias bajo campañas de vigilancia intensa alcanzaron valores altos de éxito reproductor, mostrando que las campañas de vigilancia del gobierno en conjunción con los voluntarios de diferentes ONGs constituyen un enfoque muy eficaz para reducir la caza furtiva. También llevamos a cabo un análisis de sensibilidad de la población para proporcionar datos sobre los factores que más afectan la interpretación del modelo. Aunque el crecimiento de la población y el tamaño medio de población final varía con aumentos y disminuciones en la mortalidad y la capacidad de carga, sólo 
la caza furtiva dio como resultado una probabilidad del $100 \%$ de extinción en 20 a 40 años. Para promover la conservación de aves marinas en regiones como las Islas Canarias, un archipiélago central para especies de aves marinas en el Atlántico, el control de la caza furtiva debe ser elevado por la sociedad a un nivel de urgencia, requiriendo financiación especialmente dedicada a tal fin y la movilización de expertos y voluntarios con experiencia para su adecuada dirección a través de la educación, la prevención y la correcta aplicación de las leyes.

\section{Introduction}

Habitat loss and the introduction of mammalian predators are major causes of declining seabird populations (e.g. McChesney and Tershy 1998, Towns et al. 2006). However, the impact of human harvesting of seabirds (termed poaching when illegal) is often overlooked when assessing their conservation status or threats to it. Seabirds have been extensively exploited historically (Feare 1984, Monteiro et al. 1996, Granadeiro 2006) for food, oil, feathers or guano (e.g. Cott 1953, Spennemann 1998, Muñoz del Viejo et al. 2004). They are especially vulnerable to largescale harvesting as they nest synchronously in large, dense colonies, often on the ground (Feare 1984, Hunter et al. 2000).

On the Atlantic islands of Macaronesia in particular, seabirds have been exploited historically, and this was considered the main cause of population decline (Zino 1985, Monteiro et al. 1996, Lorenzo 2004, Granadeiro et al. 2006). These activities were (and still are) mainly concentrated on the most abundant species, Cory's Shearwater Calonectris diomedea borealis. This subspecies is found in the Azores and Madeira (hosting c. $85 \%$ of the breeding pairs) and the Canary Islands (c.15\%) (del Hoyo et al. 1992, BirdLife International 2004). Chicks and fledglings are usually harvested from their burrows by hand or hook, although dogs, ferrets and smoke were also used in the past (Barker-Webb and Berthelot 1841, Castroviejo 1965, Pallarés 1987). Adults were also taken in historic times (Monteiro et al. 1996, Rando et al. 1997, Granadeiro et al. 2006), or shot for pleasure from boats while sitting on the water on flotsam (adults and fledglings) (Martín and Lorenzo 2001).

In the Selvagens Islands, harvesting was particularly intense at around 20,000 chicks per year, or even 30,000 in good years (Glas 1764, Barker-Webb and Berthelot 1841, Hartog et al. 1980 and references therein). The last harvesting expedition to Selvagem Grande occurred in 1967 (13,000 birds; Hartog et al. 1980). The species was exploited mostly by people from Madeira who later sold them (Torriani 1590). From the $16^{\text {th }}$ to the late $20^{\text {th }}$ centuries, Canary islanders also took advantage of this resource by killing, salting and transporting birds back for sale on their home islands (Torriani 1590, Glas 1764, Barker-Webb and Berthelot 1841, Bolle 1855). These episodes reduced the Selvagem Grande population to $5-7 \%$ of the original numbers, causing a major population collapse (Zino 1985, Granadeiro et al. 2006). Permanent wardening and strict protection of the island, along with the return of non-breeding birds that were away from the colonies during past harvesting episodes, might be the main causes of the continuing recovery of the population (Granadeiro et al. 2006).

Although poaching was (and is still) intense in the Azores (Monteiro et al. 1996), detailed information is scarce.

In the Canary Islands, shearwaters were exploited by indigenous inhabitants (Rando et al. 1997). After the Spanish conquest, they still constituted a source of food to survive the severe famines that occurred between the $16^{\text {th }}$ and $19^{\text {th }}$ centuries. There was trade in chick down (used for example to fill mattresses or decorate traditional hats on islands such as El Hierro) and oils (popularly reputed as medicinal; Viera y Clavijo 1866). The best organised shearwater hunting expeditions in the Canary Islands were those to the small islands of Alegranza and La Graciosa during the $16^{\text {th }}$ century. These birds were a major source of income and food for the inhabitants of Lanzarote, the nearby main island (Torriani 1590, Lobo Cabrera and Bruquetas de Castro 1995). The largest harvesting episode there was at the end of the $19^{\text {th }}$ century $(12,000$ birds; Hernández-Pacheco 1909; but see Martín and Lorenzo 2001), though the numbers decreased 
during the $20^{\text {th }}$ century $(6,000-7,000$ birds at the beginning of the century, de la Hoz 1962, Pallarés 1987, Martín and Lorenzo 2001; 4,000-5,000 around the middle of the century, Lovegrove 1971). The last major harvesting episode in Alegranza occurred in 1983 (3,000 birds; Martín and Lorenzo 2001). Harvesting of Cory's Shearwaters was first prohibited in the Canaries from the 1970s onwards (Law 1/1970). However, that protection was not effective until reinforced with a new and more restrictive law published in 1989 (Law 4/89). More recently, protection was strengthened, with a 600-6,000 Euro fine per chick (DL $1 / 2000$ ). Despite its illegality, poaching is still known to be intense and widespread on the islands of Lanzarote, Fuerteventura, and surrounding islets (La Graciosa, Montaña Clara and Isla de Lobos).

This paper aims ( $I$ ) to quantify for the first time the current effects of the poaching of chicks on breeding success of Cory's Shearwater in the Canary Islands, (2) to assess the effects of poaching on the conservation of colonies through a population sensitivity analysis, and (3) to test whether intensive surveillance/wardening campaigns are an effective management strategy to reduce poaching in the Canaries.

\section{Methods}

\section{Study sites}

Because of their illegal status, poaching activities are very difficult to quantify in the Canary Islands and precise data on their intensity is lacking. Thus, study sites were selected based on our long experience and that of the wardens working in the field with Cory's Shearwaters, checking the places where the latest cases of poaching were reported, and after many hours talking with the older inhabitants of the islands (poachers in the past), which helped us to understand their current habits and poaching sites. We selected three sample islands according to the assumed intensity of poaching they suffer: 1) Fuerteventura, where poaching is intense, 2) Isla de Lobos, where poaching is low to medium intensity, reduced due to annual government surveillance campaigns, and 3) Gran Canaria, where poaching has apparently ceased.

On Fuerteventura, the study nests were located close to Montaña Roja, on a 2-5 $\mathrm{m}$ high coastal cliff flanked by Barranco de las Pilas to the north and Barranco de las Salinas to the south $(1.3 \mathrm{~km}$ long). On Isla de Lobos, nests were mainly located in La Caldera, whereas on Gran Canaria they were located in three breeding nuclei on the north coast (Barranco del Lagarto, Caleta de Arriba, and El Cardonal) and three on the south-west coast (Barranco de Las Pardelas, Cañada del Perchel, and Veneguera) (Figure 1). However, all samples from Gran Canaria were treated as a single group as no significant differences in breeding success were found among them.

\section{Measuring breeding success (poaching vs. non-poaching)}

Breeding success (number of successful breeding pairs/ total number of pairs) was measured from 2006 to 2008 on Fuerteventura and Isla de Lobos and from 2004 to 2006 on Gran Canaria. All selected nests were occupied by one breeding pair who laid only one egg. We visited each nest four times between May and late October each year (before and after laying, after hatching, and during the pre-fledgling period). We recorded the presence or absence of chicks and eggs and noted any sign of predation (by introduced rats, mice or cats) or poaching in the vicinity of failed nests. Failure was attributed to poaching when any sign of illegal activities was detected near nests (e.g. abundant down scattered at nest entrances or presence of hooks) or when nests failed after midSeptember (poaching begins around 15 September; Castroviejo 1965, pers. obs.) and no sign of predation was noted. Only those burrows occupied by a pre-fledgling chick on the last visit were considered successful. Inter-colony and inter-annual breeding success was compared using $\chi^{2}$ and t-tests run in STATISTICA 6.1 (StatSoft 2003). 


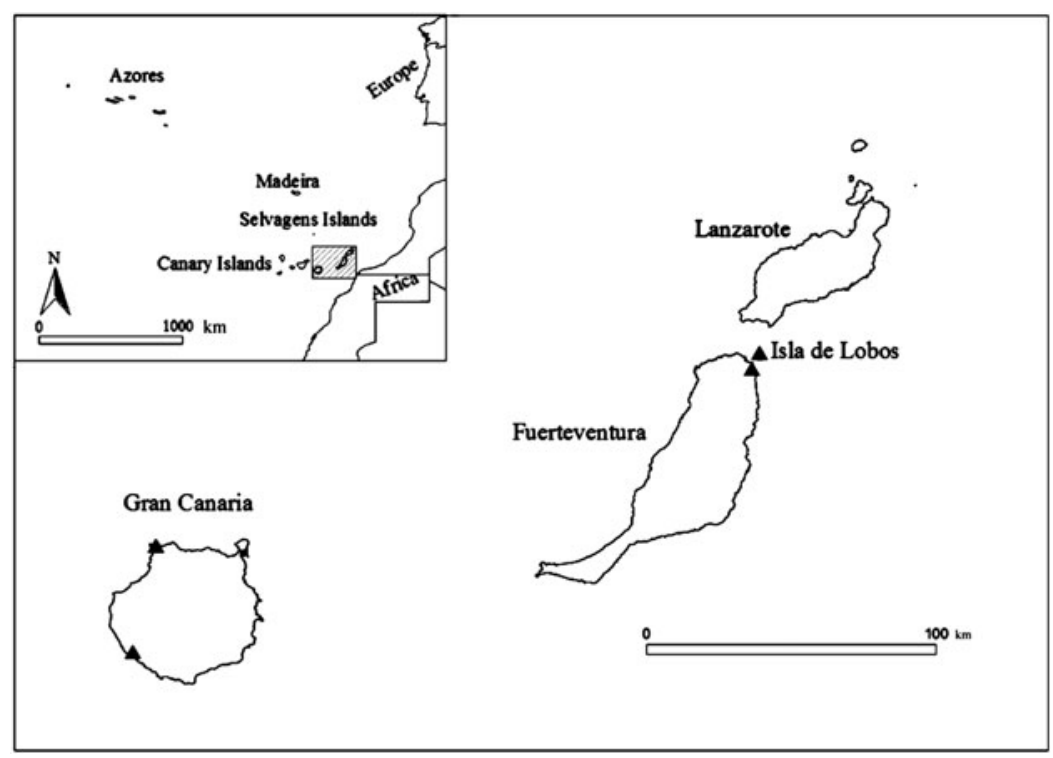

Figure 1. Geographical location of the Macaronesian archipelagos of Azores, Madeira and the Canaries, also showing the location of the studied colonies on Gran Canaria, Fuerteventura and Isla de Lobos.

\section{Implications of poaching for the conservation of Cory's Shearwater colonies}

To estimate how influential poaching is for the fate of populations, we conducted a population sensitivity analysis to identify which parameters most affected the performance of the model (Reed et al. 2002). All simulations were run in Vortex version 9.99 (Lacy 2009). Running a precise population model requires a large amount of high quality data, otherwise the results can be erroneous and must be interpreted cautiously (Reed et al. 2002). As we lack such data for the species in the Canaries, the modelling incorporated either data published on the species (or similar species) in other regions of the world, or data based on our knowledge of the species in these islands. Since the simulations are stochastic, to ensure stabilisation of the results (Harris et al. 1987), 10o iterations were run and projected for 100 years. To simplify our analysis and relax the pressure of any other negative event on the fate of the population, no catastrophes were modelled. We defined extinction when $n<50$, and treated our population as closed with the aim of simplifying the model and avoiding speculation when adding unknown data about dispersion. Inbreeding depression was not modelled as it is not likely to affect the species (Rabouam et al. 200o). Environmental variability in reproduction and mortality was modelled to be concordant. We assumed that Cory's Shearwaters were long-term monogamous birds (Swatschek et al. 1994; Rabouam et al. 2000; but see Bried et al. 2010). Age of first breeding for females and males was set at four (see Jenouvrier et al. 2008), and maximum age of reproduction at 25 because, although it is known that shearwaters show great senescence (see e.g. Hamilton and Moller 1995), the exact age for this species is unknown in the archipelago. The sex ratio at birth was assumed to be slightly biased toward males (55.4\%; Bretagnolle and Thibault 1995). No explicit densitydependent parameters were introduced. Based on our own previous data from Gran Canaria, the probability of female reproduction was set at $64 \% \pm 5.4$. The maximum number of offspring per female per year was specified to be one in all cases (Martín and Lorenzo 2001). Overall mortality 
was firstly modelled following published data from other regions: $40 \%$ at an age from $0-1$, reduced to $5 \%$ in subsequent juvenile ages (see Ristow et al. 1990; Jenouvrier et al. 2008). Annual adult mortality was assumed to be $9 \%$ (Mougin et al. 1984). Environmental variability on mortality was arbitrarily modelled at $2 \%$ for all ages. In different scenarios, mortality was increased by (i) $20 \%$ and (ii) $10 \%$, and reduced by (iii) $20 \%$ and (iv) $10 \%$ at every age stage. We randomly (v) increased by $20 \%$ and (vi) decreased by $20 \%$ the percentage of adult males available in the breeding pool. A stable age distribution was assumed for the whole population. The initial size of the population was set at 500 (approximate size assumed for a small colony such as the ones selected for our study). A moderate- to large-scale decline in carrying capacity of the island, with an environmental variation of 50 , was modelled from 500 to (i) 700 , (ii) 600, (iii) 400 , and (iv) 30o. The carrying capacity can be highly variable, depending on factors such as food availability or habitat destruction, so these stochastic fluctuations were modelled as an annual variation of $10 \%$ over 100 years (Song 1996, Marmontel et al. 1997). Harvesting was incorporated into three different rationales: low, medium and high intensity of poaching (a total of 20, 50 and 100 chicks harvested per year in the colony, respectively), with no sex bias in harvesting; these scenarios could reliably reflect what happens in the field. Immigration was set to zero for initial simulations and no genetic management was considered.

\section{Testing intense surveillance as a measure to reduce poaching}

To measure the effect of intensive surveillance on breeding success we undertook a strict campaign at Montaña Roja during 2008. Although government surveillance campaigns occur each year on Isla de Lobos, they are known to be rather ineffective, so their success was not evaluated. Montaña Roja was the colony affected by poachers that had not been guarded at all during previous years. Thus, 20 volunteers from different regional conservation NGOs in close cooperation with governmental guards were involved in monitoring the nests. The area was visited daily during the whole poaching season, and three metallic signs in the vicinity of the study area warned that the site was under surveillance. Additionally, the campaign was announced through local media.

\section{Results}

Poaching on Fuerteventura was found to be intense, reducing breeding success of the colony to almost one third of that recorded in areas with less or no harvesting (Figure 2). During the intense surveillance/wardening campaign of 2008, however, poaching was clearly reduced and breeding success was significantly higher when compared to other islands and years $(0.79$; Table 1$)(P<$ o.01). Comparing the two islands subject to poaching, loss of nests attributed to this cause was significantly higher on Fuerteventura than Isla de Lobos during 2006 and $2007(P>0.05)$, but not during the 2008 breeding season $\left(\chi^{2}=2.54, P>0.05\right)$. Poaching on Fuerteventura was the main cause of failure during years 2006 and $2007(P<0.01)$; whereas during the intensive 2008 campaign, a significantly lower failure of nests was caused by poaching than by other causes $(P<$ 0.01) (Figure 2, Table 1). On Isla de Lobos, the number of nests that failed in 2007 and 2008 due to poaching was not significantly higher than those lost for other reasons $(P>0.05)$. In 2006, however, poaching was significantly lower than other years and causes $(P<0.01)$. The proportion of nests that failed from the egg to chick stages showed no significant difference within the Gran Canaria and Fuerteventura colonies between the different years $(P<$ O.01 $)$, although it was significantly lower on Isla de Lobos in $2007(P<0.01)$. In general, the number of nests that failed during the egg to chick stages followed the cline Gran Canaria $>$ Isla de Lobos $>$ Fuerteventura, with significant differences only between Gran Canaria and Fuerteventura $\left(\chi_{1}^{2}=4.10, P<0.05\right)$.

Our population sensitivity analysis showed that our modelled Cory's Shearwater colony was highly sensitive to variation in carrying capacity and to changes in overall mortality with respect 


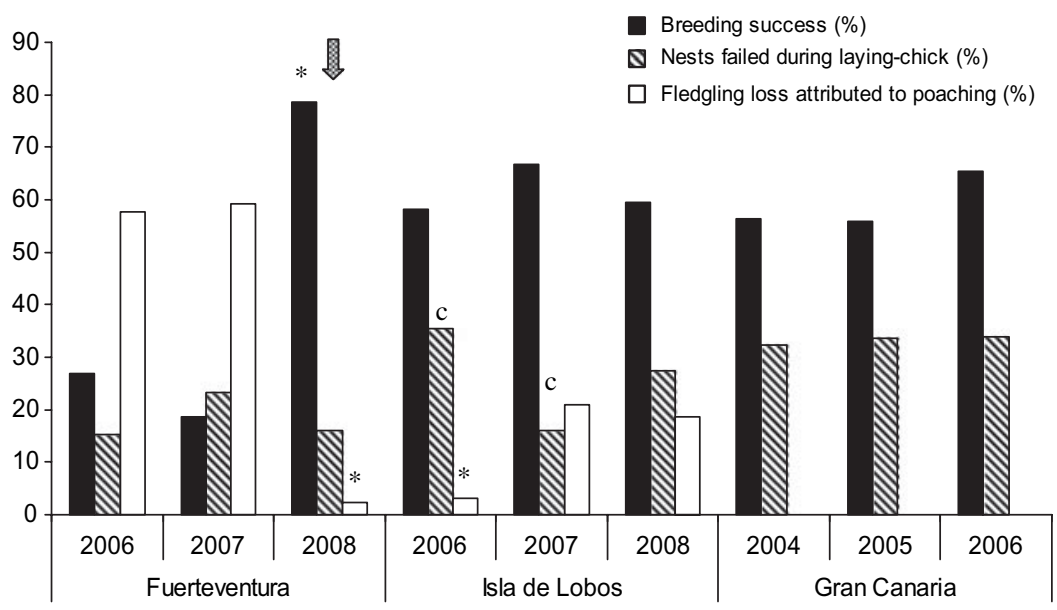

Figure 2. Breeding success (\%), nests failed during laying-chick stage (\%), and fledgling loss attributed to poaching (\%) by years on Fuerteventura, Isla de Lobos and Gran Canaria. The arrow marks the year and colony subject to the intense surveillance campaign.

to projected growth over 100 years. However, none of these parameters predicted the extinction of the colony; indeed it showed a 100\% probability of survival over 100 years, in all modelled scenarios (Table 2). Nevertheless, the prospective simulations assessed by adding low, medium and high poaching intensities to our initial population revealed that the model was very sensitive to this parameter and that poaching has the potential to greatly increase the risk of extinction (Table 2). When combining different poaching intensities with the most optimistic and pessimistic mortality and carrying capacity scenarios (optimistic: $20 \%$ decrease in overall mortality, $\mathrm{K}=700$ or 500; pessimistic: $20 \%$ overall mortality increase, $\mathrm{K}=300$ or 500 ), almost all scenarios predicted a $100 \%$ probability of extinction within $20-40$ years. Only the scenarios modelled with a combination of low intensity of poaching, a $20 \%$ decrease in overall mortality, and $\mathrm{K}=700$ or 500 showed a $100 \%$ probability of survival over 100 years, which decreased to $76 \%$ when $\mathrm{K}=$ 300 (Table 2).

\section{Discussion}

Poaching still occurs in the Canary Islands, particularly on Fuerteventura and Isla de Lobos. Its effects on the breeding success of certain Cory's Shearwater colonies was demonstrated to be

Table 1. Number of control nests, breeding pairs that initiated reproduction (\%), nests failed during layingchick stage and after poaching started (\%), fledgling loss attributed to poaching (\%) and breeding success (\%) per year on Fuerteventura (Montaña Roja), Isla de Lobos, and Gran Canaria. Isla de Lobos was guarded during the whole period, but wardening was not intense, while Montaña Roja was intensively guarded during 2008.

\begin{tabular}{|c|c|c|c|c|c|c|c|c|c|}
\hline & \multicolumn{3}{|c|}{ Fuerteventura } & \multicolumn{3}{|c|}{ Isla de Lobos } & \multicolumn{3}{|c|}{ Gran Canaria } \\
\hline & 2006 & 2007 & 2008 & 2006 & 2007 & 2008 & 2004 & 2005 & 2006 \\
\hline Number of nests monitored & 26 & 30 & 44 & 31 & 31 & 40 & 62 & 89 & 56 \\
\hline Breeding pairs initiating reproduction (\%) & 100 & 90 & $95 \cdot 5$ & 100 & $77 \cdot 4$ & 80 & 100 & 96.6 & 98.2 \\
\hline Nests failed during laying-chick (\%) & $15 \cdot 4$ & $23 \cdot 3$ & 15.9 & $35 \cdot 5$ & 16.1 & $27 \cdot 5$ & 32.3 & $33 \cdot 7$ & $33 \cdot 9$ \\
\hline Fledgling loss after poaching started (\%) & $57 \cdot 7$ & 56.7 & 6.8 & 6.5 & 22.6 & $17 \cdot 5$ & 3.2 & $\mathrm{o}$ & 1.8 \\
\hline Fledgling loss attributed to poaching (\%) & $57 \cdot 7$ & 63.0 & 7.1 & 6.5 & 29.2 & 21.9 & o & o & $\mathrm{o}$ \\
\hline Breeding success & 0.27 & 0.17 & 0.75 & 0.58 & 0.52 & 0.48 & 0.56 & 0.54 & 0.65 \\
\hline
\end{tabular}


Table 2. Results of the population sensitivity analysis examining the effect of a range of potential scenarios on a small, isolated colony of Cory's Shearwater in the Canary Islands, projected for 100 years. Sensitivity of output is shown when increasing and decreasing overall mortality $(\mathrm{M})$, carrying capacity $(\mathrm{K})$, or introducing harvesting $(\mathrm{H})$ at low, medium and high intensities. Results of another two scenarios combining the three main variables that change model output are included. The table shows: (I) probability of extinction (\%) (PE; bold if extinct), (2) mean final population (N), (3) median time of extinction (MD TE), if the population became extinct in at least $50 \%$ of the simulations, and (4) mean time to extinction of those simulated populations that became extinct (MA TE).

\begin{tabular}{|c|c|c|c|c|c|}
\hline Scenario & & $\mathrm{PE}$ & $\mathrm{N} \pm \mathrm{SD}$ & MedianTE & MeanTE \\
\hline \multirow[t]{12}{*}{ Base scenario } & & o & $5385.7 \pm 82.8$ & o & o \\
\hline & $\mathrm{M}=+20 \%$ & o & $5434.7 \pm 56.5$ & o & o \\
\hline & $M=+10 \%$ & o & $5416.5 \pm 78.4$ & o & o \\
\hline & $M=-10 \%$ & o & $3375.2 \pm 1129.9$ & o & o \\
\hline & $\mathrm{M}=-20 \%$ & o & $674.2 \pm 294.8$ & o & o \\
\hline & $\mathrm{K}=700$ & o & $7530.5 \pm 177.3$ & o & o \\
\hline & $K=600$ & o & $6443.5 \pm 171.6$ & o & o \\
\hline & $\mathrm{K}=400$ & o & $4286.5 \pm 108.4$ & o & o \\
\hline & $\mathrm{K}=300$ & o & $3196.4 \pm 125.6$ & o & o \\
\hline & $\mathrm{H}=100$ & 100 & $o \pm 0$ & 19 & 19.1 \\
\hline & $\mathrm{H}=50$ & 100 & $o \pm 0$ & 21 & 21.1 \\
\hline & $\mathrm{H}=2 \mathrm{O}$ & 100 & $o \pm 0$ & 21 & 21.1 \\
\hline \multicolumn{6}{|c|}{ Scenario 1: Mortality - 20\% } \\
\hline \multirow[t]{3}{*}{$\mathrm{K}=700$} & $\mathrm{H}=100$ & 100 & $o \pm 0$ & 21 & 21.1 \\
\hline & $\mathrm{H}=50$ & 100 & $o \pm 0$ & 26 & 27.6 \\
\hline & $\mathrm{H}=2 \mathrm{O}$ & $\mathrm{O}$ & $7612.4 \pm 57.0$ & o & o \\
\hline \multirow[t]{3}{*}{$\mathrm{K}=500$} & $\mathrm{H}=100$ & 100 & $0 \pm 0$ & 21 & 20.9 \\
\hline & $\mathrm{H}=50$ & 100 & $0 \pm 0$ & 25 & 26.5 \\
\hline & $\mathrm{H}=2 \mathrm{O}$ & $\mathrm{o}$ & $5420.9 \pm 58.1$ & o & o \\
\hline \multirow[t]{3}{*}{$\mathrm{K}=300$} & $\mathrm{H}=100$ & 100 & $0 \pm 0$ & 19 & 18.6 \\
\hline & $\mathrm{H}=50$ & 100 & $o \pm 0$ & 19 & 19.4 \\
\hline & $\mathrm{H}=2 \mathrm{O}$ & 76 & $735.7 \pm 1345 \cdot 3$ & 43 & $39 \cdot 9$ \\
\hline \multicolumn{6}{|c|}{ Scenario 1: Mortality +20\% } \\
\hline \multirow[t]{3}{*}{$\mathrm{K}=700$} & $\mathrm{H}=100$ & 100 & $0 \pm 0$ & 17 & $17 \cdot 3$ \\
\hline & $\mathrm{H}=50$ & 100 & $o \pm 0$ & 18 & 18.4 \\
\hline & $\mathrm{H}=2 \mathrm{O}$ & 100 & $o \pm 0$ & 29 & 28.9 \\
\hline \multirow[t]{3}{*}{$\mathrm{K}=500$} & $\mathrm{H}=100$ & 100 & $0 \pm 0$ & 18 & 17.5 \\
\hline & $\mathrm{H}=5 \mathrm{O}$ & 100 & $o \pm 0$ & 18 & 18 \\
\hline & $\mathrm{H}=2 \mathrm{O}$ & 100 & $o \pm 0$ & 27 & 27.8 \\
\hline \multirow[t]{3}{*}{$\mathrm{K}=300$} & $\mathrm{H}=100$ & 100 & $0 \pm 0$ & 15 & 15 \\
\hline & $\mathrm{H}=50$ & 100 & $o \pm 0$ & 15 & 14.7 \\
\hline & $\mathrm{H}=2 \mathrm{O}$ & 100 & $o \pm 0$ & 18 & 18.2 \\
\hline
\end{tabular}

negative and intense, reducing this to almost a third of what might be expected in colonies without poaching. A high number of nests (more than a third in some cases: Table 1 ) failed during the early stages, probably due to the impact of introduced mice, rats and feral cats on Gran Canaria and Fuerteventura, and mice on Isla de Lobos. Also, we clearly demonstrate that intense surveillance-wardening campaigns can be an effective management strategy in controlling poaching, directly augmenting the breeding success of the colonies and later improving their conservation status. Such campaigns should be carried out more intensively, since despite the annual government surveillance campaign on Isla de Lobos, we confirmed it to be inefficient because poaching on that islet still caused almost $30 \%$ of nests to fail in certain years (Table 1 ).

Population sensitivity analysis showed a high sensitivity to poaching in the model, which was the only input parameter that threatened colony survival at all intensities simulated (Table 2). 
Quantitative predictions of population sensitivity analyses are however strongly dependent on the quality of the ecological data used in structuring the model and the input parameters (Brook and Kikkawa 1998; Reed et al. 2002). Although most of our data may well be reliable as inferred from known data for the species in the Canaries or other regions, our modelled results should be interpreted cautiously, as some other parameters (e.g. immigration or catastrophes) were not modelled and are probably also important regarding population survival. To model the effect of poaching more accurately and to produce more realistic predictions, we would ideally have used parameter estimates based on long-term monitoring of the population (Reed et al. 2002). Nevertheless, our results provide constructive insights into factors that most affect the probability of population growth or extinction, and can at least be treated as a hypothesis to be tested. With this in mind, we can predict that poaching intensities such as those observed on Fuerteventura are likely to cause a decrease in numbers or even cause the colony to become extinct. Our observations in other colonies on that island might support this assumption: only one breeding pair was found in 2005 in the colony at Montaña Escanfraga, where poaching was known to have been highly intensive in the last three decades. A similar level of harvesting in some other colonies on Fuerteventura may be assumed, even higher in areas of the nearby Lanzarote. For instance, a colony of around Ioo breeding pairs on La Graciosa was completely harvested of chicks during 2000 (authors' unpubl. data). It would be unrealistic, however, to extrapolate this assumption to all the colonies of the eastern islands (Lanzarote, Fuerteventura and offshore islets), as the intensity of harvesting can be highly variable, depending on factors such as accessibility of the colony or the attitudes of neighbouring human populations (see Bell et al. 2007). The outcome of our sensitivity analysis should be only extrapolated to colonies similar to our model. Thus, understanding which parameters affect the fate of the whole population of Cory's Shearwater in the Canaries may need to be approached differently.

While in most developing countries subsistence needs are often the primary cause for poaching (e.g. Pratt et al. 2004), as it was in the past in the Canaries, reasons for its persistence in developed countries are less understandable. Motivations probably include enjoyment of hunting as an open-air recreation, a resistance to perceived impositions by the authorities, an act of rebellion or an exercise of traditional rights (Muth 1998, Muth and Bowe 1998, Bell et al. 2007). In the easternmost Canary Islands, poaching has turned into an activity that wealthy people participate in, sometimes including local and regional politicians. Indeed, one was prosecuted in regionally famous cases in Lanzarote in both 1996 and 2007. More recently, with the intention of avoiding being caught and prosecuted, people buy Cory's Shearwater chicks from third parties, turning poaching activities into an emerging black market which is popularly known to be supported by more people each year, who wish to earn an extra salary during their regular work holidays (I0O euros were paid per chick in 2007). The lack of social and political awareness of the impact of poaching has led to employed rangers feeling discouraged and not actively monitoring the colonies. Many of their accusations have not been acted on while they personally suffer the social pressure of having betrayed their neighbours. In fact, our results show that their monitoring on Isla de Lobos had not diminished the loss of nests due to poaching. Recently, with the aim of implementing effective colony surveillance, some NGOs are independently leading wardening activities. These are, however, equally ineffective in most cases because the volunteers do not have legal authority to detain or report illegal hunters, nor typically the expertise to deal with them, and so avoid them in practice. We have demonstrated that surveillance/wardening can be very effective in reducing poaching, if done in close cooperation between NGOs and government rangers, complementing each other's roles.

Cory's Shearwater colonies are usually well-dispersed and to completely eliminate poaching by patrolling all of them would be an arduous and unprofitable objective. In calm weather, it is possible to land undetected at a large number of sites on rugged and inaccessible cliffs where shearwaters breed. As long as illicit harvesting remains under control, the impact of poaching is regarded as tolerable in the public mind (Muth 1998). Thus, in the struggle against poaching, it is 
essential to change public opinion and highlight it as a major humane and environmental issue, not only in the Canary Islands but in other regions of the world where seabirds are massively harvested, sometimes under neither management nor control. A nearby example is Cape Verde, where thousands of chicks of the endemic Calonectris edwardsii (now considered a full species after having been split from Cory's Shearwater and categorised as 'Near Threatened' by IUCN) are harvested yearly, and probably during the last few centuries (BirdLife International 2010 and references therein). An important step in combating poaching would be the development of environmental education schemes for children and adults to encourage change in community attitudes, and more effective surveillance (involving trained experienced people, ideally government guards) and law enforcement programmes.

Based on our results, we urge that poaching be added to the official list of current threats to Cory's Shearwater conservation in the Canary Islands and management actions be implemented to adequately address it. Future management of seabirds in the Canary Islands, and by extension in other Macaronesian archipelagos, should be improved by increasing our knowledge of the effects of harvesting seabird populations.

\section{Acknowledgements}

We are highly grateful to more than 20 volunteers who made possible the Fuerteventura surveillance campaign during 2008. The Concejalía de Cultura del Ayuntamiento de La Oliva and Consejería de Medio Ambiente (Cabildo de Fuerteventura) helped us with lodging. Lázaro Sánchez-Pinto and Aurelio Martín provided us with essential historic references. Dr. Daniel Oro and another anonymous reviewer made pertinent suggestions to the manuscript that greatly improved the final version. Financial support from Obra Social de Caja de Canarias was crucial to carrying out this work.

\section{References}

Barker-Webb, M. M. P. and Berthelot, S. (1841) Historie naturelle des Iles Canaries. Vol. II. Contenant La Zoologie. Paris, France: Béthune Ed.

Bell, S., Hampshire, K. and Topalidou, S. (2007) The political culture of poaching: a case study from northern Greece. Biodivers. Conserv. 16: 399-418.

BirdLife International (2004) Birds in Europe: population estimates, trends and conservation status. Cambridge, UK: BirdLife International.

BirdLife International (2010) Species factsheet: Calonectris edwardsii. Downloaded from http://www.birdlife.org on 3/8/2010.

Bolle, C. (1855) Bemerkungen über die Vögel der Canarischen Inseln. J. Ornithol. 3: 171-181.

Bretagnolle, V. and Thibault, J. C. (1995) Method for sexing fledglings in Cory's shearwaters and comments on sex-ratio variation. The Auk 112: 785-790.

Bried, J., Dubois, M.-P., Jarne, P., Jouventin, P. and Santos, R. S. (2010) Does competi- tion for nests affect genetic monogamy in Cory's shearwater Calonectris diomedea? J. Avian Biol. 41: 407-418.

Brook, B. W. and Kikkawa, J. (1998) Examining threats faced by island birds: a population viability analysis on the Capricorn Silvereye using long-term data. J. Appl. Ecol. 35: 491-503.

Castroviejo, J. (1965) Los "pardeleros" de Canarias. Ardeola 10: 59-60.

Cott, H. B. (1953) The exploitation of wild birds for their eggs. Ibis 95: 409-449.

De la Hoz, A. (1962) Lanzarote. Madrid: Gobierno Civil de Las Palmas. Cabildo Insular de Gran Canaria y Ayuntamientos y Cabildo Insular de Lanzarote.

Del Hoyo, J., Elliott, A. and Sargatal, J., eds. (1992) Handbook of the birds of the world. Vol. I. Barcelona: Lynx Edicions.

Feare, C. J. (1984) Human Exploitation. Pp. 691-699 in J. P. Croxall, P. G. H. Evans, and R. W. Schreiber, eds. Status and conservation of the world's seabirds. Cambridge, U.K: International Council for Bird Preservation. 
Glas, G. (1764) The history of the discovery and conquest of the Canary Islands. London, UK: R. and J. Dodsley.

Granadeiro, J. P., Dias, M. P., Rebelo, R., Santos, C. D. and Catry, P. (2006) Numbers and population trends of Cory's Shearwater Calonectris diomedea at Selvagem Grande, Northeast Atlantic. Waterbirds 29: 56-60.

Hamilton, S. and Moller, H. (1995) Can PVA models using computer packages offer useful conservation advice? Sooty Shearwaters Puffinus griseus in New Zealand as a case study. Biol. Conserv. 73: 107-117.

Hartog, J. C., Nørrevang, A. and Zino, P. A. (1980) Bird Observations in the Selvagens Islands (21-23 October 1978 and 27 May-7 June 1980). Bol. Mus. Mun. Funchal 36: III-141.

Harris, R. B., Maguire, L. A. and Shaffer, M. L. (1987) Sample sized for minimum viable population estimation. Conserv. Biol. I: $72-76$.

Hernández-Pacheco, E. (1909) Estudio geológico de Lanzarote y de las isletas canarias. Mem. Real. Soc. Hist. Nat. 6: 1-236.

Hunter, C. M., Moller, H. and Kitson, J. (2000) Muttonbirder selectivity of sooty shearwater (titi) chicks harvested in New Zealand. New Zeal. J. Zool. 27: 395-414.

Jenouvrier, S., Tavecchia, G., Thibault, J.-C., Choquet, R. and Bretagnolle, V. (2008) Recruitment processes in long-lived species with delayed maturity: estimating key demographic parameters. Oikos 117: 620-628.

Lacy, R. C., Borbat, M. and Pollak, J. P. (2009) VORTEX: a stochastic simulation of the extinction process. Version 9.95. Brookfield, Illinois: Chicago Zoological Society.

Lobo Cabrera, M. and Bruquetas de Castro, F. (1995) Don Agustín de Herrera y Rojas, I Marqués de Lanzarote. Fuerteventura: Servicio de publicaciones del Cabildo de Fuerteventura.

Lorenzo, J. A. (2004) Pardela cenicienta, Calonectris diomedea borealis. Pp. 43-45 in A. Madroño, C. González and J. C. Atienza, eds. Libro Rojo de las aves de España. Madrid: Dirección General para la BiodiversidadSEO/BirdLife.

Lovegrove, R. (1971) B.O.U. supported expedition to the northeast Canary Islands. July-August 1970. Ibis 113: 269-272.
Marmontel, M., Humphrey, S. and O'Shea, T. O. (1997) Population viability analysis of the Florida Manatee (Trichechus manatus latirostris), 1976-1991. Conserv. Biol. 11: 467-481.

Martín, A. and Lorenzo, A. (2001) Aves del archipiélago canario. La Laguna, Tenerife: Francisco Lemus Ed.

McChesney, G. J. and Tershy, B. R. (1998) History and status of introduced mammals and impacts to breeding seabirds on the California channel and northwestern Baja California islands. Col. Waterbirds 21: 335-347.

Monteiro, L. R., Ramos, J. A. and Furness, R. W. (1996) Past and present status and conservation of the seabirds breeding in the Azores Archipelago. Biol. Conserv. 78: 319-328.

Mougin, J.-L., Jouanin, C. and Roux, F. (1984) Quelques aspects de la biologie de reproduction du Puffin cendre Calonectris diomedea borealis des Iles Selvagens. L'oiseau 54: 229-246.

Muñoz del Viejo, A., Vega, X., González, M. A. and Sánchez, J. M. (2004) Disturbance sources, human predation and reproductive success of seabirds in tropical coastal ecosystems of Sinaloa State, Mexico. Bird Conserv. Int. 14: 191-202.

Muth, R. M. (1998) The persistence of poaching in advanced industrial society: meanings and motivations-An introductory comment. Soc. Nat. Res. 11: 5-7.

Muth, R. M. and Bowe, J. F. Jr. (1998) Illegal harvest of renewable natural resources in North America: toward a typology of the motivations for poaching. Soc. Nat. Res. 11: 9-24.

Pallarés, A. (1987) Técnicas de caza de la pardela en nuestra Isla (I-III). Lancelot 202-204: 46, 39, 44.

Pratt, D. G., MacMillan, D. C. and Gordon, I. J. (2004) Local community attitudes to wildlife utilization in the changing economic and social context of Mongolia. Biodivers. Conserv. 13: 591-613.

Rabouam, C., Bretagnolle, V., Bigot, Y. and Periquet, G. (2000) Genetic relationships of Cory's shearwater: parentage, mating assortment, and geographic differentiation revealed by DNA fingerprinting. The Auk 117: 651-662. 
Rando, J. C., Lopez, M. and Jimenez, M. C. (1997) Bird remains from the archaeological site of Guinea (El Hierro, Canary Islands). Int. J. Osteoarch. 7: 298-302.

Reed, J. M., Mills, L. S., Dunning, J. B. Jr., Menges, E. S., McKelvey, K. S., Frye, R., Beissinger, S. R., Anstett, M.-C. and Miller, P. (2002) Emerging issues in population viability analysis. Conserv. Biol. 16: 7-19

Ristow, D., Feldmann, F., Scharlau, W. and Wink, M. (1990) Populationsstruktur, Geburtsortstreue und Mortalität des Gelbschnabelsturmtauchers (Calonectris d. diomedea). Vogelwelt 111: 172-181.

Song, Y. (1996) Population viability analysis for two isolated populations of Hainan Eld's deer. Conserv. Biol. 10: 1467-1472.

Spennemann, D. H. R. (1998) Excessive exploitation of central Pacific seabird populations at the turn of the $20^{\text {th }}$ century. Marine Ornithol. 26: 49-57.

StatSoft, Inc. (2003) STATISTICA (data analysis software system), version 6. www. statsoft.com.
Swatschek, I., Ristow, D. and Wink, M. (1994) Mate fidelity and parentage in Cory's shearwater Calonectris diomedea-field studies and DNA fingerprinting. Mol. Ecol. 3: 259-262.

Torriani, L. (1590) Descripción e historia del reino de las Islas Canarias, antes Afortunadas, con el parecer de su fortificaciones. Translated by A. Cioranescu Tenerife: Goya.

Towns, D. R., Atkinson, I. A. E. and Daugherty, C. H. (2006) Have the harmful effects of introduced rats on islands been exaggerated? Biol. Invasions 8: 863-891.

Viera y Clavijo, J. (1866) Diccionario de historia natural de las Islas Canarias o Índice alfabético descriptivo de sus tres reinos animal, vegetal y mineral. Las Palmas de Gran Canaria, Canary Islands, Spain: Real Sociedad Económica de Amigos del País. Imprenta de la Verdad.

Zino, P. A. (1985) Pequeno apontamento histórico sobre a caça das cagarras na Selvagem Grande e desenvolvimentos recentes nesta ilha. Boc. 84: 1-14.

\section{MARTA LOPEZ-DARIAS*}

Island Ecology and Evolutionary Resarch Group, Instituto de Productos Naturales y Agrobiología (IPNA-CSIC), Ave. Astrofisico Francisco Sanchez 3, 38206-San Cristobal de La Laguna, Tenerife, Canary Islands, Spain.

JAVIER LUZARDO, DANIEL GONZÁLEZ, EDUARDO A. GARCÍA, JEREMÍAS CABRERA Asociación Amigos de la Pardela Cenicienta. Paseo Miramar, 111. B2, E2, 3․ 35414-Arucas, Gran Canaria, Canary Islands, Spain.

\section{RAFAEL MARTÍNEZ}

Asociación Amigos de la Pardela Cenicienta. Paseo Miramar, 111. B2, E2, $3^{\circ}$. 35414-Arucas, Gran Canaria, Islas Canary Islands, Spain.

Unidad de Agentes de Medio Ambiente. Cabildo de Fuerteventura. C/ San Roque, 14. 35600 Puerto del Rosario, Fuerteventura, Canary Islands, Spain.

*Author for correspondence; email: mdarias@ipna.csic.es

Received 28 October 2009; revision accepted 4 August 2010; Published online 11 April 2011 